\title{
Is Insulin Resistant Brain State a Central Feature of the Metabolic-Cognitive Syndrome?
}

\author{
Vincenza Frisardi ${ }^{\mathrm{a}, *}$, Vincenzo Solfrizzi ${ }^{\mathrm{a}}$, Cristiano Capurso $^{\mathrm{b}}$, Bruno P. Imbimbo ${ }^{\mathrm{c}}$, \\ Gianluigi Vendemiale $^{\mathrm{b}}$, Davide Seripa ${ }^{\mathrm{d}}$, Alberto Pilotto ${ }^{\mathrm{d}}$ and Francesco Panza ${ }^{\mathrm{d}, *}$ \\ ${ }^{a}$ Department of Geriatrics, Center for Aging Brain, Memory Unit, University of Bari, Bari, Italy \\ ${ }^{\mathrm{b}}$ Department of Geriatrics, University of Foggia, Foggia, Italy \\ ${ }^{\mathrm{c}}$ Research \& Development Department, Chiesi Farmaceutici, Parma, Italy \\ ${ }^{\mathrm{d}}$ Geriatric Unit and Gerontology-Geriatrics Research Laboratory, Department of Medical Sciences, IRCCS Casa \\ Sollievo della Sofferenza, San Giovanni Rotondo, Foggia, Italy
}

Accepted 3 March 2010

\begin{abstract}
Cumulative evidence suggests that metabolic syndrome (MetS) may be important in the development of mild cognitive impairment, vascular dementia, and Alzheimer's disease (AD). As such, these patients might be described as having "metaboliccognitive syndrome" - MetS plus cognitive impairment of degenerative or vascular origin. While peripheral insulin resistance appears to be of primary pathophysiological importance in MetS, the definitions of MetS and its components do not include any reference to insulin resistance or hyperinsulinemia. In the present article, we discuss the role of these factors in the development of cognitive decline and dementia, including underlying mechanisms that influence amyloid- $\beta$ (A $\beta$ ) peptide metabolism and tau protein hyperphosphorylation, the principal neuropathological hallmarks of AD. In AD, an age-related desynchronization of biological systems results, involving stress components, cortisol and noradrenaline, reactive oxygen species, and membrane damage as major candidates that precipitates an insulin resistant brain state (IRBS) with decreased glucose/energy metabolism and the increased formation of hyperphosphorylated tau protein and $\mathrm{A} \beta$. Unfortunately, it is very difficult to include the measurement of peripheral insulin resistance in the current MetS criteria or the identification of IRBS for the metabolic-cognitive syndrome. However, since inflammation has been suggested among the MetS components, we propose IRBS as an additional feature of the metabolic-cognitive syndrome to also identify a molecular profile in patients at high risk of developing predementia or dementia syndromes.
\end{abstract}

Keywords: Amyloid- $\beta$ peptide metabolism, hyperinsulinemia, hyperphosphorylated tau protein, insulin resistance, insulin resistant brain state, metabolic syndrome, type 2 diabetes mellitus

\footnotetext{
${ }^{*}$ Correspondence to: Vincenza Frisardi, M.D., Department of Geriatrics, Center for Aging Brain, Memory Unit, University of Bari, Policlinico, Piazza Giulio Cesare, 11 - 70124 Bari, Italy. E-mail: vfrisardi@yahoo.com; Francesco Panza, M.D., Ph.D., Geriatric Unit and Gerontology-Geriatric Research Laboratory, IRCCS Casa Sollievo della Sofferenza, Viale Cappuccini 1, 71013 San Giovanni Rotondo, Foggia, Italy. E-mail: geriat.dot@geriatria.uniba.it.
}

\section{INTRODUCTION}

Metabolic syndrome (MetS) is a multifactorial disorder represented by the co-occurrence of several conditions related to central obesity that also includes impaired glucose metabolism, lower high density lipoprotein levels, elevated triglyceride levels, and high blood pressure and that depicts a risk status for both type 2 diabetes mellitus (T2DM) and coronary artery dis- 
ease $[1,2]$. However, one of the more controversial topics regarding MetS is whether it poses cardiovascular risk beyond what is already conferred by the vascular risk factors that comprise it $[3,4]$. Furthermore, MetS did not consistently predict total and cardiovascular mortality in older men, especially at age 70 [5], whereas it has been shown to be independently associated with predementia and dementia syndromes. The time of measurement of MetS and some MetS components seems to be of crucial importance. In fact, hypertension [6] and elevated body mass index in middle age may be associated with higher dementia risk [7, 8], while the association between MetS and accelerated cognitive decline disappeared at the age of 85 and older [9]. MetS appears to increase the risk for agerelated cognitive decline [9-15] and vascular dementia (VaD) [16-19], while contrasting findings exist for mild cognitive impairment (MCI) [20-22], its progression to dementia, and Alzheimer's disease (AD) $[16,18$, 19,23-25]. These suggestions permitted us to hypothesize the presence of a "metabolic-cognitive syndrome (MCS)" in patients with MetS plus cognitive impairment of degenerative or vascular origin that could help us better understand clinical and neuropathological features of these cognitive disorders. The identification of a clinical profile of this MCS could also be central in detecting a molecular profile of higher risk to develop predementia or dementia syndrome.

\section{INSULIN RESISTANCE, METABOLIC SYNDROME, AND COGNITIVE DECLINE}

Except for the World Health Organization criteria [2], the European Group for study of Insulin Resistance criteria [26], and the American Association of Clinical Endocrinologists criteria [27], the principal definitions of MetS do not include any reference to insulin resistance or hyperinsulinemia despite clear evidence that these factors play a causal role in its occurrence in most patients, even if the presence of insulin resistance cannot be taken for granted in patients with MetS. The occurrence of diabetes and dementia is very high in older patients, suggesting a possible link between the two, overall because diabetic patients have a higher chance of developing dementia [29]. T2DM has also been found consistently to be related to vascular dementia but its relation to AD is less clear, although half of the studies found an increased risk in diabetic patients $[29,30]$. In type 1 diabetes mellitus (T1DM), only a mild decrease of speed of informa- tion processing and psychomotor efficiency has been shown in nondemented subjects [31], while inT2DM, memory and executive functions have been found to be impaired [32]. One clue as to why T1DM and T2DM may differ in the progression of cognitive impairment is a potential interaction between diabetes and age [33]. In fact, T2DM is more prevalent with increasing age, and clinically relevant decreases in cognitive function are more likely to occur in elderly T2DM patients [34]. Another possible explanation for the differential effects on cognitive function is insulin resistance, a feature more prevalent in T2DM than in T1DM [33].

In fact, some authors hypothesized that insulin resistant brain state (IRBS) contributes to cognitive impairment and neurodegeneration. Several aspects of brain metabolism clearly responded to insulin action, and although insulin and insulin-like growth factor 1 (IGF1) are supplied by circulation, a smaller proportion of insulin is produced in the brain itself [35]. Moreover, insulin receptors (IRs) have been found in different brain areas with variable densities, in particular, in the olfactory bulb, hypothalamus, cerebral cortex, and hippocampus [36]. Therefore, impairments of insulin and IGF-1 signaling leads to decreased energy metabolism and increased oxidative stress manifested by reduced glucose uptake and ATP production [37]. Reduced ATP adversely affects cellular homeostasis, membrane permeability, and fundamental processes required for synaptic maintenance and remodeling, which are needed for learning and establishing new memory [38]. In addition to a metabolic function, insulin and IGF-1 modulate neuronal growth, survival, differentiation, migration, gene expression, protein synthesis, cytoskeletal assembly, synapse formation, and plasticity. In addition, they regulate growth, survival, and myelin production/maintenance in oligodendrocytes [39]. On the other hand, hyperglycemia, diabetes mellitus, and insulin resistance increased the risk of developing cerebrovascular disease, microand macrovascular complications of varying severity [33], as well as increased carotid intima-media thickness [40-42], or greater grade of infarcted areas during a cerebrovascular event [43]. Increased concentrations of anti-fibrinolytic and other procoagulant factors have been found in diabetes mellitus as well as alterations in nitric oxide metabolism. Plasminogen activator inhibitor-1 and antithrombin III, which inhibit fibrinolysis, as well as the tissue plasminogen activator antigen, a marker of impaired fibrinolysis, were consistently found to be elevated in insulin resistance phenotypes $[44,45]$. Procoagulant factors, such as factor VII and VIII, and the von-Willebrand factor also rise with the degree of insulin resistance $[46,47]$. 


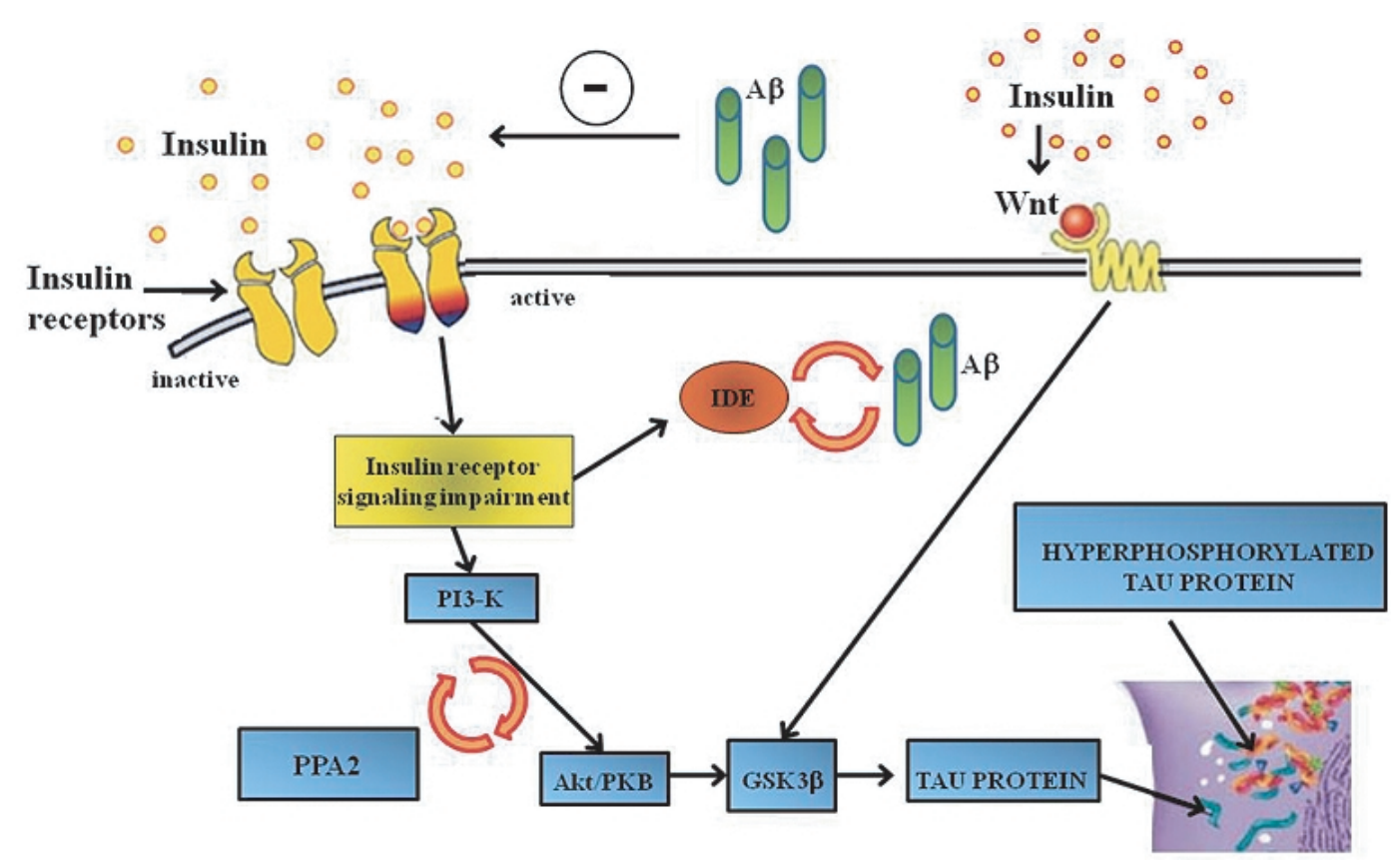

Fig. 1. Overview of the principal underlying mechanisms linking insulin resistance to Alzheimer's disease (AD). A $\beta=$ amyloid- $\beta$; IDE $=$ insulin degrading enzyme; PI3-K = phosphatidylinositol-3 kinase; Akt/PKB = protein kinase B; GSK-3 $\beta=$ glycogen synthase kinase-3 $\beta$; $\mathrm{PP} 2 \mathrm{~A}=$ protein phosphatase 2 .

\section{INSULIN RESISTANCE BRAIN STATE AND TAU PROTEIN}

Insulin and IGF-1 after binding to IRs mediate signal transduction by activation of phosphatidylinositol3 kinase (PI3-K) that stimulates glucose transport and inhibits apoptosis by activating protein kinase $\mathrm{B}$ (Akt/PKB) [38]. Insulin resistance signaling impairment induces PI3-K dysfunction leading to reduced Akt/PKB activity, decreased glucose/energy metabolism, and ATP production, compromising all ATP-dependent processes, which may include also insulin degrading enzyme (IDE) activity regulation [48]. Additionally, PI3-K dysfunction leads to reduced glycogen synthase kinase $3 \alpha / \beta$ (GSK-3 $\alpha / \beta)$ phosphorylation, and by GSK-3 $\alpha / \beta$ activation, to phosphorylation of tau protein and intraneuronal amyloid$\beta$ (A $\beta)$ accumulation (Fig. 1). The understanding of this mechanism allowed new perspectives into research of disease-modifying drugs, such as GSK3 inhibitors [49]. Glucose metabolism also participates in posttranslational protein modification involving the hexosamine biosynthetic pathway, which leads to the generation of O-N-acetylglycosamine (O-GlcNAc). OGlcNAcylation of proteins is proposed to compete with protein phosphorylation, and if intraneuronal glucose metabolism decreases because of insulin resistance,
O-GlcNAcylation is decreased and consequently increased protein phosphorylation, including tau protein [50].

There is now solid evidence that insulin and IGF-1 signaling cascades are involved in expression and phosphorylation regulation of tau protein and also in cytoskeletal functions via phosphorylation [51]. Recently, in a mice experimental model, two distinct mechanisms were hypothesized to explain the role of impaired insulin signaling in tau hyperphosphorylation [52]. One, inherent to insulin depletion, probably causes inhibition of the PI3K/Akt pathway, in particular by inhibition of protein phosphatase 2 (PP2A) activity and increasing activation of GSK-3 $\beta$ [53]. In addition, inhibition of insulin/IGF-1 signaling blocks the Wnt pathway [54], which negatively regulates GSK-3 $\beta$ via a PI3K/Aktindependent mechanism. In $\mathrm{AD}$, both PI3K/Akt and Wnt signaling have been linked to key molecular abnormalities [55]. The other mechanism was consequent to hypothermia. In fact, deficits in peripheral glucose/energy metabolism lead to relative hypothermia, with direct inhibition of PP2A activity, finally resulting in hyperphosphorylation of tau [52], which cannot be transported into axons, and that then accumulates and aggregates in neuronal perikarya [56]. This contributes to neurodegeneration by enhancing oxidative stress and triggering pathophysiological cascades 
that lead to increased apoptosis destabilizing the microtubule network and other cellular functions [57].

\section{INSULIN RESISTANT BRAIN STATE AND AMYLOID- $\beta$}

Insulin also influences $\mathrm{A} \beta$ peptide metabolism by accelerating its trafficking to the plasma membrane from the trans-Golgi network, where it is generated. Insulin also increases extracellular levels of amyloid$\beta$ protein precursor $(\mathrm{A} \beta \mathrm{PP})$ by promoting its secretion and inhibiting its degradation by IDE and, finally, disrupting physiological processing of $\mathrm{A} \beta \mathrm{PP}$ [38] (Fig. 1). Conversely, alterations in insulin signaling may be secondary and not primary factors in relation to $\mathrm{AD}$. In particular, extracellular soluble oligomers of $\mathrm{A} \beta$ peptides [also termed $\mathrm{A} \beta$-derived diffusible ligands (ADDLs)] [58] can bind to synapses and decrease membrane IRs through an insulin signaling-dependent mechanism $[59,60]$. Intracellular $\mathrm{A} \beta$ inhibits insulin signaling in neurons by interfering with the association between phosphoinositide-dependent kinase 1 and Akt1 and precluding Akt1 activation [59,60]. Therefore, since $\mathrm{A} \beta \mathrm{PP}$ competes with insulin for receptor binding, inefficient degradation of soluble $\mathrm{A} \beta \mathrm{PP}$ could represent an important mediator of brain insulin resistance in AD through a competitive mechanism with IDE $[61,62]$. If $\mathrm{A} \beta \mathrm{PP}$ interferes with IDE function, the outcome should be to increase rather than decrease insulin levels and their actions in the central nervous system (CNS). Nonetheless, in AD, the opposite is true, i.e., increased levels of $\mathrm{A} \beta \mathrm{PP}$ are associated with reduced levels of CNS insulin and IGF-1 [63]. This suggests that a dual mechanism of cognitive impairment and neurodegeneration mediated by insulin resistance is possible and that it may be distinguished the brain insulin deficiency action from peripheral insulin resistance. In the absence of peripheral insulin resistance, AD most likely represents a brain-specific form of diabetes mellitus, i.e., type 3 diabetes mellitus (T3DM) due to the combined effects of brain insulin deficiency and insulin resistance. Because etiological factors responsible for T3DM have not been clearly proven in the case of sporadic AD [64], some authors proposed the term IRBS instead of "T2DM confined to the brain" or T3DM to avoid misunderstandings. With aging, desynchronization of biological processes, together with the activity of susceptibility genes (e.g., apolipoprotein E), hypothalamic-pituitary-adrenal (HPA) axis impairment (i.e., cortisol and noradrenalin) and oxida- tive injury may induce an IRBS [48]. From a diagnostic point of view, after a 1-minute cold pressure test, both cortisol and noradrenaline increased in sporadic $\mathrm{AD}$ patients, indicating HPA-axis hyperactivity and an increased sympathetic tone significantly higher than in age-matched controls [65]. The induction of an IRBS may be of predominating significance for the generation of sporadic AD in absence of MetS. On the contrary, besides the mechanism speculated above, among individuals with peripheral insulin resistance, there is another pathological process relative to excess generation of cytotoxic lipids, including ceramides, that cross the blood-brain barrier and cause IRBS, neuro-inflammation, oxidative stress, DNA damage, and lipid peroxidation [38]. Ceramides are lipid signaling molecules with wide-ranging modulatory effects, including cell proliferation, motility, plasticity, inflammation, apoptosis, and insulin resistance [66]. In particular, ceramides cause insulin resistance by activating pro-inflammatory cytokines and also inhibiting insulin-stimulated signaling through PI3-K/Akt in the brain [38]. Finally, impaired insulin signaling increases oxidative stress by expression of pro-oxidant genes belonging to nitrous oxide systems, incorporation of 8 hydroxy-2'-deoxyguanosine, which destabilizes DNA, lipid peroxidation with 4-hydroxynonenal accumulation, and activation of pro-apoptosis genes. In fact, the progressive worsening of insulin/IGF resistance with regard to stage of AD is correlated with all these cellular alterations but in a different manner according to whether the insulin resistance disease is in or outside the CNS.

\section{CONCLUSIONS}

A growing body of evidence from epidemiological and basic research has proposed a model of cognitive impairment of vascular or degenerative origin linked to MetS and metabolic disorders. This MCS may have as central feature, the IRBS, notwithstanding the absence in current operational clinical criteria for MetS of insulin resistance or hyperinsulinemia. However, although the hypothesis that the IRBS and MetS may be important for AD pathogenesis, they are distinct entities and may not be related to each other. Elucidation of the interactions among various metabolic disorders and identification of convergent pathophysiology underlying comorbidities will likely provide important clues to dementia-related mechanisms. In fact, there is very strong evidence that obesity, hyperinsulinemia, 
and $\mathrm{T} 2 \mathrm{DM}$ are related to dementia and AD. The potential mechanisms linking the continuum of obesity, hyperinsulinemia, and T2DM are multiple, overlapping, and highly correlated. Conversely, obesity is also strongly associated with hypertension via hypothalamic activation of the sympathetic nervous system by leptin [67]. Clearly, it is very difficult to include the measurement of peripheral insulin resistance in the current research-applied MetS criteria or the identification of IRBS for the MCS. However, as inflammation has been suggested for inclusion among the MetS components in the few last years [68], we proposed the IRBS as an additional feature of the MCS to identify in these patients a molecular profile of higher risk to develop predementia or dementia syndromes.

\section{ACKNOWLEDGMENTS}

This work was supported by the Italian Longitudinal Study on Aging (ILSA) (Italian National Research Council - CNR-Targeted Project on Ageing - Grants 9400419PF40 and 95973PF40) and Ministero della Salute, IRCCS Research Program 2009-2011, Line 2: "Malattie complesse".

Authors' disclosures available online (http://www.jalz.com/disclosures/view.php?id=362).

\section{REFERENCES}

[1] Avogaro P, Crepaldi G, Enzi G, Tiengo A (1967) Association of hyperlipemia, diabetes mellitus and mild obesity. Acta Diabetol Lat 4, 572-590.

[2] Alberti KG, Zimmet PZ (1998) Definition, diagnosis and classification of diabetes mellitus and its complications. Part 1: diagnosis and classification of diabetes mellitus provisional report of a WHO consultation. Diabet Med 15, 539-553.

[3] Gami AS, Witt BJ, Howard DE, Erwin PJ, Gami LA, Somers VK, Montori VM (2007) Metabolic syndrome and risk of incident cardiovascular events and death: a systematic review and metaanalysis of longitudinal studies. J Am Coll Cardiol 49, 403-414.

[4] Inchiostro S, Fadini GP, de Kreutzenberg SV, Citroni N, Avogaro A (2007) Is the metabolic syndrome a cardiovascular risk factor beyond its specific components? J Am Coll Cardiol 49, 2465.

[5] Sundström J, Risérus U, Byberg L, Zethelius B, Lithell H, Lind L (2006) Clinical value of the metabolic syndrome for long term prediction of total and cardiovascular mortality: prospective, population based cohort study. BMJ 332, 878882 .

[6] Kivipelto M, Helkala E-L, Laakso MP, Hänninen T, Hallikainen M, Alhainen K, Iivonen S, Mannermaa A, Tuomilehto J, Nissinen A, Soininen H (2000) Apolipoprotein E $\varepsilon 4$ allele, elevated midlife total cholesterol level and high midlife systolic blood pressure are independent risk factors for late-life Alzheimer's disease. Ann Intern Med 137, 149-155.
[7] Kivipelto M, Ngandu T, Fratiglioni L,Viitanen M, Kareholt I, Winblad B, Helkala EL, Tuomilehto J, Soininen H, Nissinen A (2005) Obesity and vascular risk factors at midlife and the risk of dementia and Alzheimer disease. Arch Neurol 62, 15561560 .

[8] Whitmer RA, Gunderson EP, Barrett-Connor E, Quesenberry $\mathrm{CP}$, Jr, Yaffe K (2005) Obesity in middle age and future risk of dementia: a 27 year longitudinal population based study. BMJ 330, 1360.

[9] van den Berg E, Biessels GJ, de Craen AJ, Gussekloo J, Westendorp RG (2007) The metabolic syndrome is associated with decelerated cognitive decline in the oldest old. Neurology 69 979-985.

[10] Yaffe K, Kanaya A, Lindquist K, Simonsick EM, Harris T, Shorr RI, Tylavsky FA, Newman AB (2004) The metabolic syndrome, inflammation, and risk of cognitive decline. JAMA 292, 2237-2242.

[11] Dik MG, Jonker C, Comijs HC, Deeg DJ, Kok A, Yaffe K, Penninx BW (2007) Contribution of metabolic syndrome components to cognition in older individuals. Diabetes Care 30, 2655-2660.

[12] Yaffe K, Haan M, Blackwell T, Cherkasova E, Whitmer RA, West N (2007) Metabolic syndrome and cognitive decline in elderly Latinos: findings from the Sacramento Area Latino Study of Aging study. J Am Geriatr Soc 55, 758-762.

[13] Komulainen P, Lakka TA, Kivipelto M, Hassinen M, Helkala EL, Haapala I, Nissinen A, Rauramaa R (2007) Metabolic syndrome and cognitive function: a population-based followup study in elderly women. Dement Geriatr Cogn Disord 23, 29-34.

[14] Ho RC, Niti M, Yap KB, Kua EH, Ng TP (2008) Metabolic syndrome and cognitive decline in chinese older adults: results from the Singapore longitudinal ageing studies. Am J Geriatr Psychiatry 16, 519-522.

[15] Lee KS, Jang Y, Chung YK, Chung JH, Oh BH, Hong CH (2009) Relationship between the diagnostic components of metabolic syndrome (MS) and cognition by ApoE genotype in the elderly. Arch Gerontol Geriatr 50, 69-72.

[16] Kalmijn S, Foley D, White L, Burchfiel CM, Curb JD, Petrovitch H, Ross GW, Havlik RJ, Launer LJ (2000) Metabolic cardiovascular syndrome and risk of dementia in JapaneseAmerican elderly men. The Honolulu-Asia aging study. Arterioscler Thromb Vasc Biol 20, 2255-2260.

[17] Roriz-Cruz M, Rosset I, Wada T, Sakagami T, Ishine M, De Sá Roriz-Filho J, Cruz TR, Hosseinkhani M, Rodrigues RP, Sudoh S, Arai H, Wakatsuki Y, Souza AC, Nakagawa M, Kita T, Matsubayashi K (2007) Cognitive impairment and frontalsubcortical geriatric syndrome are associated with metabolic syndrome in a stroke-free population. Neurobiol Aging 28, 1723-1736

[18] Raffaitin C, Gin H, Empana JP, Helmer C, Berr C, Tzourio C, Portet F, Dartigues JF, Alpérovitch A, Barberger-Gateau P (2009) Metabolic syndrome and risk for incident Alzheimer's disease or vascular dementia: the Three-City Study. Diabetes Care 32, 169-174.

[19] Solfrizzi V, Scafato E, Capurso C, D'Introno A, Colacicco AM, Frisardi V, Vendemiale G, Baldereschi M, Crepaldi G, Di Carlo A, Galluzzo L, Gandin C, Inzitari D, Maggi S, Capurso A, Panza F; Italian Longitudinal Study on Aging Working Group (2009) Metabolic syndrome and the risk of vascular dementia. The Italian Longitudinal Study on Aging. J Neurol Neurosurg Psychiatry 81, 433-440.

[20] Roberts RO, Geda YE, Knopman DS, Cha RH, Boeve BF, Ivnik RJ, Pankratz VS, Tangalos EG, Petersen RC (2009) 
Metabolic syndrome, inflammation, and nonamnestic mild cognitive impairment in older persons: a population-based study. Alzheimer Dis Assoc Disord 24, 11-18.

[21] Yaffe K, Weston AL, Blackwell T, Krueger KA (2009) The metabolic syndrome and development of cognitive impairment among older women. Arch Neurol 66, 324-328.

[22] Solfrizzi V, Scafato E, Capurso C, D’Introno A, Colacicco AM, Frisardi V, Vendemiale G, Baldereschi M, Crepaldi G, Di Carlo A, Galluzzo L, Gandin C, Inzitari D, Maggi S, Capurso A, Panza F; Italian Longitudinal Study on Aging Working Group (2009) Metabolic syndrome, mild cognitive impairment, and progression to dementia. The Italian Longitudinal Study on Aging. Neurobiol Aging, in press.

[23] Muller M, Tang MX, Schupf N, Manly JJ, Mayeux R, Luchsinger JA (2007) Metabolic syndrome and dementia risk in a multiethnic elderly cohort. Dement Geriatr Cogn Disord 24, 185-192.

[24] Vanhanen M, Koivisto K, Moilanen L, Helkala EL, Hanninen T, Soininen H, Kervinen K, Kesaniemi YA, Laakso M, Kuusisto J (2006) Association of metabolic syndrome with Alzheimer disease: A population-based study. Neurology 67, 843-847.

[25] Razay G, Vreugdenhil A, Wilcock G (2007) The metabolic syndrome and Alzheimer disease. Arch Neurol 64, 93-96.

[26] Balkau B, Charles MA (1999) Comment on the provisional report from the WHO consultation. European Group for the Study of Insulin Resistance (EGIR). Diabet Med 16, 442-443.

[27] Einhorn D, Reaven GM, Cobin RH, Ford E, Ganda OP, Handelsman Y, Hellman R, Jellinger PS, Kendall D, Krauss RM, Neufeld ND, Petak SM, Rodbard HW, Seibel JA, Smith DA, Wilson PW (2003) American College of Endocrinology position statement on the insulin resistance syndrome. Endocr Pract 9, 237-252.

[28] Schnaider Beeri M, Goldbourt U, Silverman JM, Noy S, Schmeidler J, Ravona-Springer R, Sverdlick A, Davidson M (2004) Diabetes mellitus in midlife and the risk of dementia three decades later. Neurology 63, 1902-1907.

[29] Xu WL, Qiu CX, Wahlin A, Winblad B, Fratiglioni L (2004) Diabetes mellitus and risk of dementia in the Kungsholmen project: a 6 year follow-up study. Neurology 63, 1181-1186.

[30] Luchsinger JA, Reitz C, Honig LS, Tang MX, Shea S, Mayeux R (2005) Aggregation of vascular risk factors and risk of incident Alzheimer disease. Neurology 65, 545-551.

[31] Brands AM, Biessels GJ, De Haan E, Kappelle LJ, Kessels RP (2005) The effects of type 1 diabetes on cognitive performance. A metaanalysis. Diabet Care 28, 726-735.

[32] Van Harten B, Oosterman J, Muslimovic D, Potter van Loon BJ, Scheltens P, Weinstein HC (2007) Cognitive impairment and MRI correlates in the elderly patients with type 2 diabetes mellitus. Age Ageing 36, 164-170.

[33] S Roriz-Filho J, Sá-Roriz TM, Rosset I, Camozzato AL, Santos AC, Chaves ML, Moriguti JC, Roriz-Cruz M (2009) (Pre)diabetes, brain aging, and cognition. Biochim Biophys Acta 1792, 432-443.

[34] Schoenle EJ, Schoenle D, Molinari L, Largo RH (2002) Impaired intellectual development in children with type I diabetes: association with $\mathrm{HbA}(1 \mathrm{c})$, age at diagnosis and sex. Diabetologia 45, 108-114.

[35] Plata-Salaman CR (1991) Insulin in the cerebrospinal fluid. Neurosci Biobehav Rev 15, 243-258.

[36] Unger J, McNeill TH, Moxley RT, White M, Moss A, Livingston JN (1989) Distribution of insulin receptor-like immunoreactivity in the rat forebrain. Neuroscience 31, 143-157.
[37] de la Monte SM, Wands JR (2005) Review of insulin and insulin-like growth factor expression, signaling, and malfunction in the central nervous system: relevance to Alzheimer's disease. J Alzheimers Dis 7, 45-61.

[38] de la Monte SM (2009) Insulin resistance and Alzheimer's disease. BMB Rep 42, 475-481.

[39] D'Ercole AJ, Ye P, Calikoglu AS, Gutierrez- Ospina G (1996) The role of the insulin-like growth factors in the central nervous system. Mol Neurobiol 13, 227-255.

[40] Air EL, Kissela BM (2007) Diabetes, the metabolic syndrome, and ischemic stroke: epidemiology and possible mechanisms. Diabetes Care 30, 3131-3140.

[41] Brohall G, Oden A, Fagerberg B (2006) Carotid artery intimamedia thickness in patients with type 2 diabetes mellitus and impaired glucose tolerance: a systematic review. Diabet Med 23, 609-616.

[42] Wagenknecht LE, D'Agostino R Jr, Savage PJ, O'Leary DH, Saad MF, Haffner SM (1997) Duration of diabetes and carotid wall thickness: the Insulin Resistance Atherosclerosis Study (IRAS). Stroke 28, 999-1005.

[43] Monnier L, Mas E, Ginet C, Michel F, Villon L, Cristol JP, Colette C (2006) Activation of oxidative stress by acute glucose fluctuations compared with sustained chronic hyperglycaemia in patients with type 2 diabetes. JAMA 295, 1681-1687.

[44] Aoki I, Shimoyama K, Aoki N, Homori M, Yanagisawa A, Nakahara K, Kawai Y, Kitamura SI, Ishikawa K (1996) Platelet-dependent thrombin generation in patients with diabetes mellitus: effects of glycemic control on coagulability in diabetes. J Am Coll Cardiol 27, 560-566.

[45] Meigs JB, Mittleman MA, Nathan DM, Tofler GH, Singer DE, Murphy-Sheehy PM, Lipinska I, D'Agostino RB, Wilson PW (2000) Hyperinsulinemia, hyperglycemia, and impaired hemostasis: the Framingham Offspring Study. JAMA 283, 221-228.

[46] Romano M, Guagnano MT, Pacini G, Vigneri S, Falco A, Marinopiccoli M, Manigrasso MR, Basili S, Davi G (2003) Association of inflammation markers with impaired insulin sensitivity and coagulative activation in obese healthy women. $J$ Clin Endocrinol Metab 88, 5321-5326.

[47] Mertens I, Van Gaal LF (2002) Obesity, haemostasis and the fibrinolytic system. Obes Rev 3, 85-101.

[48] S alkovic-Petrisica M, Osmanovica J, Grunblattb E, Riedererb P, Hoyerc S (2009) Insulin resistant brain state generates multiple long-term morphobiological abnormalities including hyperphosphorylated tau protein and amyloid- $\beta$. J Alzheimer Dis 18, 729-750.

[49] Frisardi V, Solfrizzi V, Imbimbo BP, Capurso C, D'Introno A, Colacicco AM, Vendemiale G, Seripa D, Pilotto A, Capurso A, Panza (2010) Towards disease-modifying treatment of Alzheimer's disease: drugs targeting beta-amyloid. Curr Alzheimer Res 7, 40-55.

[50] Liu F, Iqbal K, Grundke-Iqbal I, Hart GW, Gong CX (2004) O-GlcNAcylation regulates phosphorylation of tau: a mechanism involved in Alzheimer's diseae. Proc Natl Acad Sci U S A 101, 10804-10809.

[51] Hong M, Lee VM (1997) Insulin and insulin-like growth factor-1 regulate tau phosphorylation in cultured human neurons. J Biol Chem 272, 19547-19553.

[52] Planel E, Tatebayashi Y, Miyasaka T, Liu L, Wang L, Herman M, Yu WH, Luchsinger JA, Wadzinski B, Duff KE, Takashima A (2007) Insulin dysfunction induces in vivo tau hyperphosphorylation through distinct mechanisms. J Neurosci $27,13635-13648$ 
[53] Schubert M, Brazil DP, Burks DJ, Kushner J A, Ye J, Flint C L, Farhang-Fallah J, Dikkes P, Warot XM, Rio C, Corfas G, White MF (2003) Insulin receptor substrate-2 deficiency impairs brain growth and promotes tau phosphorylation. $J$ Neurosci 23, 7084-7092.

[54] Doble BW, Woodgett JR (2003) GSK-3: tricks of the trade for a multi-tasking kinase. J Cell Sci 116, 1175-1186.

[55] De Ferrari GV, Inestrosa NC (2000) Wnt signaling function in Alzheimer's disease. Brain Res Rev 33, 1-12.

[56] Feinstein SC, Wilson L (2005) Inability of tau to properly regulate neuronal microtubule dynamics: a loss-of-function mechanism by which tau might mediate neuronal cell death. Biochim Biophys Acta 1739, 268-279.

[57] Mandelkow EM, Stamer K, Vogel R, Thies E, Mandelkow E (2003) Clogging of axons by tau, inhibition of axonal traffic and starvation of synapses. Neurobiol Aging 24, 1079-1085.

[58] Gong Y, Chang L, Viola KL, Lacor PN, Lambert MP, Finch CE, Krafft GA, Klein WL (2003) Alzheimer's disease-affected brain: presence of oligomeric A beta ligands (ADDLs) suggests a molecular basis for reversible memory loss. Proc Natl Acad Sci U S A 100, 10417-10422.

[59] Zhao WQ, Townsend M (2009) Insulin resistance and amyloidogenesis as common molecular foundation for type $2 \mathrm{di}$ abetes and Alzheimer's disease. Biochim Biophys Acta 1792. 482-496

[60] Liao FF, Xu H (2009) Insulin signaling in sporadic Alzheimer's disease. Sci Signal 2, 36.

[61] Bernstein HG, Ansorge S, Riederer P, Reiser M, Frolich L, Bogerts B (1999) Insulin-degrading enzyme in the Alzheimer's disease brain: prominent localization in neurons and senile plaques. Neurosci Lett 263, 161-164.

[62] Cook DG, Leverenz JB, McMillan PJ, Kulstad JJ, Ericksen S, Roth RA, Schellenberg GD, Jin LW, Kovacina KS, Craft S (2003) Reduced hippocampal insulin-degrading enzyme in late-onset Alzheimer's disease is associated with the apolipoprotein E epsilon4 allele. Am J Pathol 162, 313-319.

[63] Rivera EJ, Goldin A, Fulmer N, Tavares R, Wands JR, de la Monte SM (2005) Insulin and insulin-like growth factor expression and function deteriorate with progression of Alzheimer's disease: link to brain reductions in acetylcholine. J Alzheimers Dis 8, 247-268.

[64] de la Monte SM, Neusner A, Chu J, Lawton M (2009) Epidemiological trends strongly suggest exposures as etiologic agents in the pathogenesis of sporadic Alzheimer's disease, diabetes mellitus, and non-alcoholic steatohepatitis. $J$ Alzheimers Dis 17, 519-529.

[65] Pascualy M, Petrie EC, Brodkin K, Peskind ER, Wilkinson W, Raskind MA (2000) Hypothalamic pituitary adrenocortical and sympathetic nervous system responses to the cold pressure test in Alzheimer's disease. Biol Psychiatry 48, 237-254.

[66] Holland WL, Summers SA (2008) Sphingolipids, insulin resistance, and metabolic disease: new insights from in vivo manipulation of sphingolipid metabolism. Endocr Rev 29, 381402.

[67] Rahmouni K, Correia ML, Haynes WG, Mark AL (2005) Obesity-associated hypertension: new insights into mechanisms. Hypertension 45, 9-14.

[68] Haffner SM (2006) The metabolic syndrome: inflammation, diabetes mellitus, and cardiovascular disease. Am J Cardiol 97, 3A-11A. 